\title{
Livelihoods after land reform in South Africa
}

\author{
Michael Aliber and Ben Cousins
}

\begin{abstract}
Over the past few decades, Zimbabwe, Namibia and South Africa have pursued redistributive land reform as a means to address rural poverty. The Livelihoods after Land Reform (LaLR) study was carried out between 2007 and 2009, to understand the livelihood and poverty reduction outcomes of land reform in each of the three countries. The South African component focused on Limpopo province, and investigated land reform processes, trajectories of change and outcomes in thirteen detailed case studies. This paper summarizes some of the main findings from the South African study, and briefly compares them with findings from Namibia and Zimbabwe. The paper argues that a fundamental problem affecting land reform in both South Africa and Namibia is the uncritical application of the Large-Scale Commercial Farming (LSCF) model, which has led to unworkable project design and/or projects that are irrelevant to the circumstances of the rural poor. Nevertheless, some 'beneficiaries' have experienced modest improvements in their livelihoods, often through abandoning or amending official project plans.
\end{abstract}

\section{Introduction}

Redistributive land reform has been pursued in South Africa over the past two decades. In South Africa at present, there is near-consensus that land reform has been unsuccessful, but a startling lack of agreement as to its problems and what remedies should be administered. Broadly, land reform is criticized both for its pace - about 8 per cent of commercial farmland redistributed over 18 years versus the 30 per cent over 5 years initially targeted - and its performance: the livelihoods (and production) outcomes on the 8 per cent of redistributed land on which this paper focuses.

A number of explanations have been offered for poor livelihoods and production outcomes, including: poor extension and other support to land reform 'beneficiaries' (Jacobs et al. 2003; Manenzhe 2007); ${ }^{1}$ inadequate beneficiary skills (e.g. CRLR 2004); too little money spent (and thus land transferred) per beneficiary (Jacobs et al. 2003); an economy that is hostile to small-scale entrepreneurs generally, whether in agriculture or off-farm (Philip and Hassen 2008); and a failure to subdivide large farms (Aliber and Mokoena 2003), by some accounts due to resistance from 'a conservative coalition of state

\footnotetext{
${ }^{1}$ The term 'land reform beneficiaries' is used in mainstream policy discourse to denote individuals or households who are official recipients of assistance from South Africa's land reform programme. While the term is not ideal (e.g. it implies passivity), we use it here for convenience, from now on without quotation marks.
} 
and private sector interests ...' (Lahiff 2010, 60). While each of these explanations may have some merit, this paper argues that the more fundamental problem is the South African state's stubborn commitment to the LSCF model of agriculture, notwithstanding the rhetorical embrace of smallholder agriculture in some policy documents.

The Livelihoods after Land Reform (LaLR) study, for which the fieldwork was carried out between 2007 and 2009, sought to understand the livelihood and poverty reduction outcomes of land reform in South Africa, Namibia and Zimbabwe.A specific aim was to identify how the livelihood outcomes of land reform are conditioned by policy-makers' and implementers' conceptions of 'viability'. This paper summarizes some of the main findings from the South African component of LaLR, which investigated land reform processes, trajectories of change and livelihood outcomes in thirteen detailed case studies drawn from two district municipalities, Vhembe and Capricorn, within what we refer to as 'central-north Limpopo province'. A secondary purpose is to compare these with the findings for the other two countries in the study. Both commonalities and differences are identified and briefly discussed.

For the South African case, the paper demonstrates that commitment to the LSCF model is subtly but powerfully evident in the ways in which land reform implementation systems are designed and deployed. Where the application of the LSCF model functions at all (i.e. where land reform beneficiaries manage to 'farm productively', leaving aside for now precisely what this means), the poverty reduction benefits are typically insignificant; this merely reflects the manner in which the characteristic capital-intensity of the LSCF model is out of sync with South Africa's rural unemployment crisis. More generally, the LSCF model fails to take into account social realities, not least the abilities and aspirations of rural dwellers, and results in 'land reform projects' that are intrinsically unworkable and prone to collapse. While planners' collective thrall to the concept of 'viability' is possibly the most tangible manifestation of how the LSCF model informs the implementation of land reform, it is also, ironically, the lens through which the deficiencies of land reform policies are viewed by policy-makers. Thus, for example, when it became evident in the late 1990 s that the land redistribution programme was plagued with problems of project collapse and idle land, government concluded that the problem was an inadequate adherence to the principle of viability, rather than a misapplication of the principle itself. And yet, as the paper also seeks to demonstrate, close inspection of land reform projects reveals instances in which beneficiaries have managed to work outside the restrictions imposed by policy, hinting at ways in which the government's approach to land reform could be usefully revised.

The paper confirms that the LSCF model has cast a long shadow in all three countries studied. Namibia seems the most extreme case, where the rigid norms associated with extensive livestock farming have translated into top-down imposition of farm business plans that are inappropriate to many would-be beneficiaries' aspirations and asset levels. Zimbabwe's land reform was similarly handicapped by the over-zealous application of the LSCF model, but under the A1 schemes of the Fast Track Resettlement Programme, a much greater range of farming models was accommodated, which accounts for discernibly more positive livelihood impacts, notwithstanding an unusually harsh macroeconomic environment. 


\section{South Africa's inherited agrarian structure and tentative Agrarian reform}

South Africa's 'dualistic' agrarian structure comprises around 35,000 large-scale, mostly whiteowned commercial farms, occupying the majority of the country's agricultural land and producing almost all marketed output, and a much larger number of small-scale, black farmers, largely confined to the ex-Bantustans (approximately 4 million, located in around 2 million households; Aliber et al. 2009, 4).This latter group is quite diverse, both in scale and orientation; most produce mainly for subsistence purposes and as a supplementary source of food, and a smaller number (around 200,000) mainly in order to generate monetary income. According to the 2002 agricultural census, about 5 per cent of large-scale commercial farming units accounted for about half of aggregate gross farm income, and more than 60 per cent of aggregate net farm income (Stats SA 2005). This dualism has not been much reduced by post-apartheid land reform. The main thrust of agricultural policy after 1994 was deregulation and liberalization, which appears to have facilitated higher levels of concentration of land ownership rather than opening up space for smallholders, as some economists argued (van Zyl 1996).

At the onset of democracy in 1994, the thinking of the incoming ANC government was bold and reasonably clear: it would pursue an agrarian reform that would restructure agriculture, replacing then dominant large-scale commercial farmers with smallholders. This aspiration was part and parcel of the ANC's 1994, Reconstruction and Development Programme (RDP):

A national land reform programme is the central and driving force of a programme of rural development. Such a programme aims to address effectively the injustices of forced removals and the historical denial of access to land . . . [I]n implementing the national land reform programme, and through the provision of support services, the democratic government will build the economy by generating large-scale employment, increasing rural incomes and eliminating overcrowding. (ANC 1994, §2.4.2)

The RDP was unambiguous as to the superiority of small-scale farming, making subtle but clear references to two economic precepts, namely the 'inverse farm-size productivity relationship' and the 'improved local multiplier argument'. The RDP also indicated that land reform would have three main components: redistribution, through which people would seek assistance to acquire land for farming and/or settlement; restitution, involving the restoration of land, or the provision of alternative compensation, to the victims of forced removals; and tenure reform, to improve the tenure security of the population of the ex-Bantustans and 'Coloured reserves', as well as of farm dwellers and workers on commercial farms. How these programmes would operate was set out in a 1997 White Paper on Land Policy (DLA 1997).

Beyond the stated intentions of the RDP, it is evident that at least part of government's emerging land reform programme was indeed geared towards helping small-scale farmers. Thus the original funding modality for the redistribution programme consisted of a grant of R15,000 per household, when the average price of land on the market at the time was about R900 per hectare. However, how redistribution was actually implemented up to around 2000 had little to do with small-scale farmers. Rather, in a manner 
reminiscent of Zimbabwe's Model B resettlement projects of the 1980s, which were structured as co-operatives, land redistribution projects tended to consist of beneficiary groups who pooled their settlement and land acquisition (SLAG) grants in order to acquire land, which they then generally attempted to farm as a group. There is now almost universal agreement that this was a mistake, and accounted for the widespread collapse of SLAG-financed projects (Lahiff 2007, 1589; Hall 2011, 221). In any event, the impacts of redistribution on livelihoods were questioned, which ultimately meant the end of SLAG as the primary funding vehicle for redistribution.

In 2001, a new redistribution vehicle was unveiled under the name 'Land Redistribution for Agricultural Development' (LRAD). This new policy was ostensibly non-prescriptive, allowing for group projects as well as subdivision, but stated that group projects 'will be discouraged' (MALA 2001, 4). However, the discouragement of group-based production was not balanced by favouring or facilitating subdivision of land acquired through group purchases.

LRAD allowed for a far larger grant, ranging from R20,000 to R100,000, with 'own contributions' ranging from R5,000 at the lower end (which could be paid in kind, including through 'sweat equity' labour), to R400,000 at the upper end of the scale. One of the stated aims of LRAD was to create a significant class of black commercial farmers who would acquire entire farms but without abandoning the rural poor, who could pursue 'food safety net projects'; support for farming in communal areas would also be provided (Jacobs et al. 2003, 4). In 2008, when the grants provided by LRAD still proved inadequate for the purpose of enabling families to acquire entire farms, they were increased to a maximum of R431,000 (Aliber and Hall 2010, 20). The consequence was projects to redistribute larger areas of land to individuals, but with many fewer beneficiaries.

The trajectory of the rural restitution programme reveals a less dramatic change in approach, seemingly because there is less latitude in how to define a 'restitution project': the identity of the beneficiaries and the land are mainly governed by the nature of the dispossession, rather than by government's prevailing development model. Indeed, whereas in redistribution there was a concerted attempt to move away from group farming projects, in restitution this was not a meaningful option, because the group nature of most rural claims is a given. The question remains whether government might have considered subdividing restitution projects, at least as a menu option, but there is no evidence that this has happened. Indeed, many rural restitution projects have so many claimant members that subdivision is impractical even by the standards of most hardcore smallholder enthusiasts. Among other things, this simple observation reveals the extent to which the population has grown in the intervening decades between dispossession and restoration (Walker 2008).

The 1997 White Paper on Land Policy made little mention of how land reform objectives would be supported by agricultural policies, mirrored by a corresponding failure to integrate land reform into agricultural policy. The Department of Agriculture prioritized policies of deregulation and liberalization, focused on the abolition of subsidies on credit, inputs and exports, and dismantling single-channel marketing schemes and their 
administered prices. A new Marketing Act of 1996 aimed to increase market access for all 'market participants' (a euphemism for new black commercial farmers), promote efficiency, optimize export earnings and enhance the viability of agriculture (van Schalkwyk et al. 2003, 128). The White Paper on Agriculture of 1995 (Department of Agriculture 1995, 12) stated that state interventions in marketing should be 'limited to the correction of market imperfections and socially unacceptable effects'. These policy frameworks enabled the continued consolidation of large-scale commercial farming (see Bernstein in this special issue).

One interpretation of these seemingly contradictory developments is that, notwithstanding some effort to promote a small-scale farming model in rhetoric or policy, there was a strong continuity in dominant thinking about agriculture from pre- to post1994, largely because ANC governments relied on the existing fund of 'expert knowledge', which took for granted the desirability of agricultural modernization and economies of scale (Hebinck et al. 2011) centred on the twin concepts of 'viability' and 'efficiency'. 'Viability' is typically understood as a minimum, economically feasible farm size (Cousins and Scoones 2010) - appropriately differentiated by type of cropping or animal husbandry activity - below which farmers will always struggle. The trajectory of South Africa's commercial farming sector towards fewer and larger production units (Vink and van Rooyen 2009) is meanwhile taken as evidence of the efficiencies inherent in 'economies of scale', whose tendency is to push the viability threshold ever upwards.

\section{Agriculture and land reform in Limpopo province}

The agro-ecological conditions for commercial farming in central-north Limpopo are characterized by stark contrasts, subsuming areas of high and low soil fertility, and good and poor rainfall. Accordingly, mixed farming systems are rare compared to farms specializing in extensive livestock ranching, on one hand, or intensive, irrigated orchard farming, on the other. Irrigation is mainly practised to enhance productivity in areas that already have high rainfall, rather than in arid areas to compensate for poor rainfall. This means that the trend over the past several decades towards a drier climate is felt most acutely in areas that were relatively dry to begin with. However, high-rainfall areas in which irrigation is practised are themselves under increasing water stress (DWAF 2004, vii).

This is perhaps one reason why changes in the LSCF sector of central-north Limpopo over the past 50 years or so are an exaggerated version of national trends. The pattern typical of South Africa as a whole is that the number of farming units peaked in the midtwentieth century, following by a steady decline to the present; but whereas the national trend is only a modest decline in the area under commercial farming, in central-north Limpopo the amount of land in commercial farming has declined by about half, while the number of units has dropped by 70 per cent.

This has been accompanied by a large decrease in farm employment. The number of regular farm workers declined from over 16,000 in 1952 to fewer than 5,000 in 2002 (Bureau of Census and Statistics 1953; Stats SA 2005), while the number of seasonal/casual farm workers followed a similar trend. As of March 2007, commercial agriculture in central-north Limpopo absorbed only 3.3 per cent and 2.0 per cent of the 
labour force in Vhembe and Capricorn districts, respectively. However, despite the collapse of black agriculture during the twentieth century, participation in largely 'subsistence' agriculture in the ex-Bantustans is widespread: the share of black households practising agriculture at some scale is 66.8 per cent in Vhembe and 50.2 per cent in Capricorn (Table 1). For the rural population of central-north Limpopo, the importance of agriculture lies not mainly in farm jobs, but in smallholdings and gardens in the communal areas of the ex-Bantustans.

At the time the study began in 2007, there were 119 land reform projects in Capricorn and Vhembe Districts, of which 81 were redistribution projects and 36 restitution projects. A census of the projects was conducted in order to get an overview of their status, and to lay a basis for selecting projects for in-depth case studies. As of late 2007: for 46 per cent of projects, project land was completely idle; for 40 per cent, at least some beneficiary activity on the land was discernible; 3 per cent had no beneficiary involvement, with some or all project land leased out; and for 10 per cent of projects, no information was obtainable, most likely suggesting that their land was also idle. The project census also established that among the 40 per cent of projects with at least some activity on the land, on most the numbers farming were dramatically less than the numbers of official beneficiaries.

Table 1. Agricultural employment and self-employment in Limpopo province, 2007

\begin{tabular}{lccc}
\hline & Vhembe & Capricorn & Limpopo \\
\hline Agricultural wage employment & 13,300 & 8,400 & 50,300 \\
As \% of labour force & 3.3 & 2.0 & 2.8 \\
Black households that practise agriculture & 189,900 & 168,500 & 606,500 \\
As \% of all black households & 66.8 & 50.2 & 44.4 \\
\hline
\end{tabular}

Source: Stats SA (2007).

\section{Project case studies and stylized trajectories}

From among the 40 per cent of projects in the census with some farming, forty-seven projects in all, thirteen were selected as subjects for case studies. Each case study involved up to six different fieldwork activities, namely: land-use mapping, household surveys, indepth individual interviews, focus group discussions, enterprise profiling and key informant interviews (including, where possible, with former owners). The mix and intensity of fieldwork activities varied from one case study project to another, largely because of the differences in the projects themselves - not least the numbers of beneficiaries, which varied from one to 1,000 households. Some projects were studied in relatively little depth as they have been well covered in other studies ${ }^{2}$.

Analytically, it is useful to distinguish land reform projects according to the three main types that prevailed up to 2009, namely SLAG-based redistribution projects, LRAD-based redistribution projects and restitution projects. Table 2 lists the project case studies accordingly, and indicates some of their basic parameters. Two key features to note are:

\footnotetext{
2 The main example of this is Levubu, in fact a cluster of five large, complex restitution projects in the Levubu Valley, studied by Fraser (2007), Derman et al. (2010) and Lahiff et al. (2012).
} 
(a) changes in land use following the transfer of land; and (b) the much lower numbers of beneficiaries in May 2009 compared to those listed as beneficiaries in official planning documents (with the notable exception of Munzhedzi).

The thirteen detailed case studies are reported in Aliber et al. (forthcoming). In what follows, we present one abbreviated case study for each of the three main types of land reform, together with stylized trajectories for that project type.

\section{SLAG-Based Land Redistribution Projects, 1995-20oo: Case study of Rustfontein farm/Makhamotse.}

The Rustfontein farm became part of land reform at the initiative of its owner, David L, who employed ten permanent and twenty-four temporary workers. According to his former employees, David decided to sell the farm because he was getting old and his son was not interested in taking over. One day in 1998, he called a meeting of his workers to inform them of his intention to sell the farm, and that if interested they could acquire it themselves. He explained that they would have to complete some forms and submit them to the government. Although in this particular case the workers were fond of their boss, they were delighted at the prospect of becoming owners: 'we were very happy and thought that we are now rich looking at the success that Mr L was achieving'.

David L's asking price for the farm was R1.8 million. An estate agent helped him understand how the SLAG policy worked, and advised him to request his workers to recruit additional applicants from the local area, in practice from Sekgopo, a conglomeration of villages in a communal area only a few kilometres from the boundary of Rustfontein. Another one of David L's former employees, Joshua, referred to this estate agent, as '. . . another lady who was running the programme for land reform', suggesting the extent to which SLAG was propelled by the interests of sellers rather than the needs of people seeking land. Ultimately, the SLAG application included 121 households, and the pooled grants came to R1.94 million, allowing a small surplus after paying for the land that could be used for operational expenses.

Thus Rustfontein farm became the Makhamotse land reform project in 2000. It consisted of 10 hectares of fruit orchards, 26 hectares under a variety of cash crops, 500 hectares of blue gum plantations and about 800 hectares of grazing land. As with most SLAG and restitution projects, a Communal Property Association (CPA) was constituted in order to take ownership of the land, as provided for in the Communal Property Associations Act of 1996. The beneficiary members then elected a committee to run the CPA's affairs.

Of the 121 households, ten were those of former farm workers, and the others were recruits from Sekgopo. Joshua suggests that these recruits were mainly relatives of the farm workers who recruited them. Key informants from Sekgopo said of land reform in general that most recruited beneficiaries were merely asked to allow the use of their ID numbers to boost the applicant numbers, which suggests that they had no real interest in what happened at Rustfontein. Onica M, another erstwhile farm worker who became a beneficiary, said that 'government officials confronted people in this area asking for IDs'. 


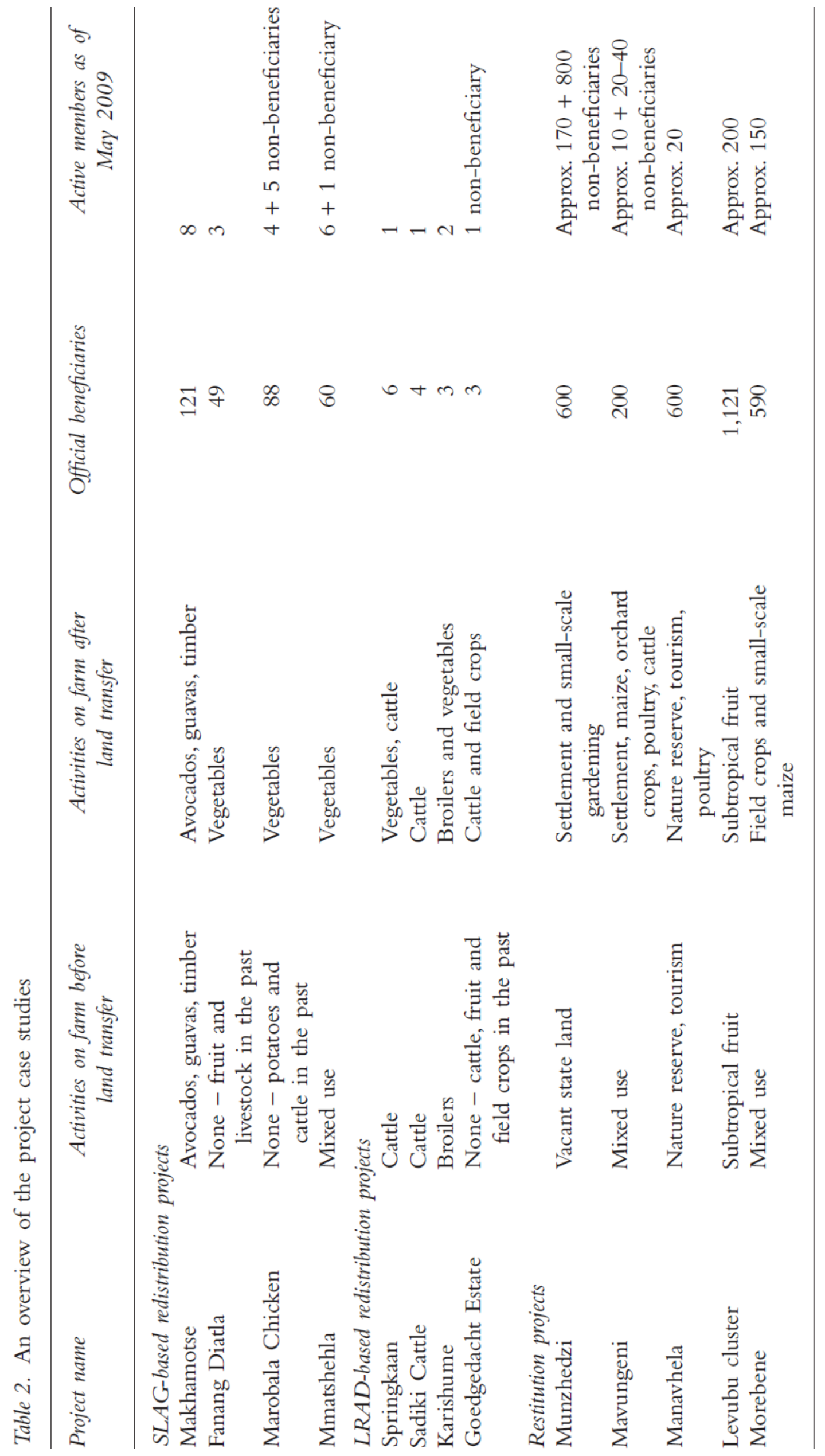

https://repository.uwc.ac.za/ 
What expectations did the recruited villagers themselves hold? Unfortunately, we failed to get direct access to their views, because violence that erupted shortly before our fieldwork began made contacting them difficult. However, Joshua gives possible clues. Asked whether the beneficiaries had ever considered subdividing the farm to allocate people their own plots, Joshua responded, 'Some [people] were interested in that, but we saw that it won't be the good way for business. Yeah, I can say it was a discussion.' And then: 'We tried [to make the project work], but some of the people had never worked before.' It would seem that the 'we' to whom Joshua refers are the former farm workers, in whose minds the 'good way for business' was to preserve the commercial farming enterprises of the previous owner, their employer. It is likely that those wishing to discuss subdivision were the recruited villagers, at least some of whom were clearly not passively allowing the use of the ID numbers. While we do not know how many were actively farmers, it is probably relevant that Sekgopo is fringed by $100-150$ communal area smallholdings with various agricultural activities. According to Onica, 'Things were not going well when they started the project and it was because of the large number of people, and the people were uncontrollable. As a result, people were only working as they wished. It was difficult to tell a person to work as they didn't have anyone to supervise them.' Onica also betrays an assumption that farming should be pursued in a particular way, namely with clear lines of authority and control.

The conflicts within the Makhamotse project may well have had multiple dimensions, but it seems clear that the difference of views about farming models was key. In effect, land reform at Rustfontein was initiated by the seller, was conceptualized as a large-scale commercial farming operation by the former farm workers who formed the core of the beneficiary group, and was implemented on this basis with no serious regard for the wishes and circumstances of the villagers recruited to make up the bulk of the beneficiary group.

What happened at Makhamotse in the years following transfer was fairly typical of SLAG based redistribution projects: declining production, lack of infrastructure maintenance and reinvestment, and paralysed decision-making. Around 2005, Joshua emerged as the new leader of the project. For 3 years, Makhamotse showed signs of recovery, but then its troubles became more extreme. Some recruited villagers who had been sidelined sabotaged the project through theft and arson, physically assaulting Joshua on one occasion and chasing him away on another.

By 2010, production had ceased altogether, and only a few households from among the original farm workers remained. Joshua, who was born and raised on Rustfontein, ended up as a tenant on another farm in the area (ironically, another abandoned land redistribution project), deeply in debt, living alone and trying to make a fresh start with some cattle borrowed from a local white farmer.

\section{Trajectories of SLAG-based projects.}

SLAG-based projects in the study began in the same way: farm workers and other beneficiaries recruited from nearby communal areas were brought together in a group project by a would-be seller; that is, they were seller-driven. The next step was also common: a dramatic decline in the number of active members, together with a drop in 
agricultural production - what we refer to in Figure 1 as 'partial collapse'. At this stage, it is useful to note what is not observed (indicated with dashed lines): any SLAG projects maintaining continuity in either active membership or in production, or any projects subdividing the land and allocating it to individual beneficiaries. This is not to say that these two alternative trajectories never occur, but we are not aware of any such cases in Limpopo, and surmise that they are rare. The non-occurrence of subdivision following land redistribution is a much-discussed policy issue in South Africa (van den Brink et al. 2006; Lahiff 2007).

From 'partial collapse', we observed three different trajectories and note one that was not observed (project recovery in terms of both production and active membership). By contrast, what was observed was the following:

(i) A very small core of residual active members manage to rescue the project, as happened at Fanang Diatla, followed by an expansion of production and an increase in the number of employees. The fact that Fanang Diatla did not try to invite back some of the departed beneficiaries is interesting, but it seems clear why not - the remaining core membership wishes to maintain control of the farm, which it can do with employed workers, but not necessarily if other beneficiaries return.

(ii) An outside investor or lessee arrives and restarts production, employing some remaining beneficiaries and possibly others. We know from elsewhere in Limpopo that the investor or lessee can be an established white commercial farmer, but in our cases these were local black entrepreneurs seeking to rent land from SLAG beneficiaries as a means of diversifying into agriculture, and who then hire some of the beneficiaries as farm workers.

Figure 1 SLAG project trajectories

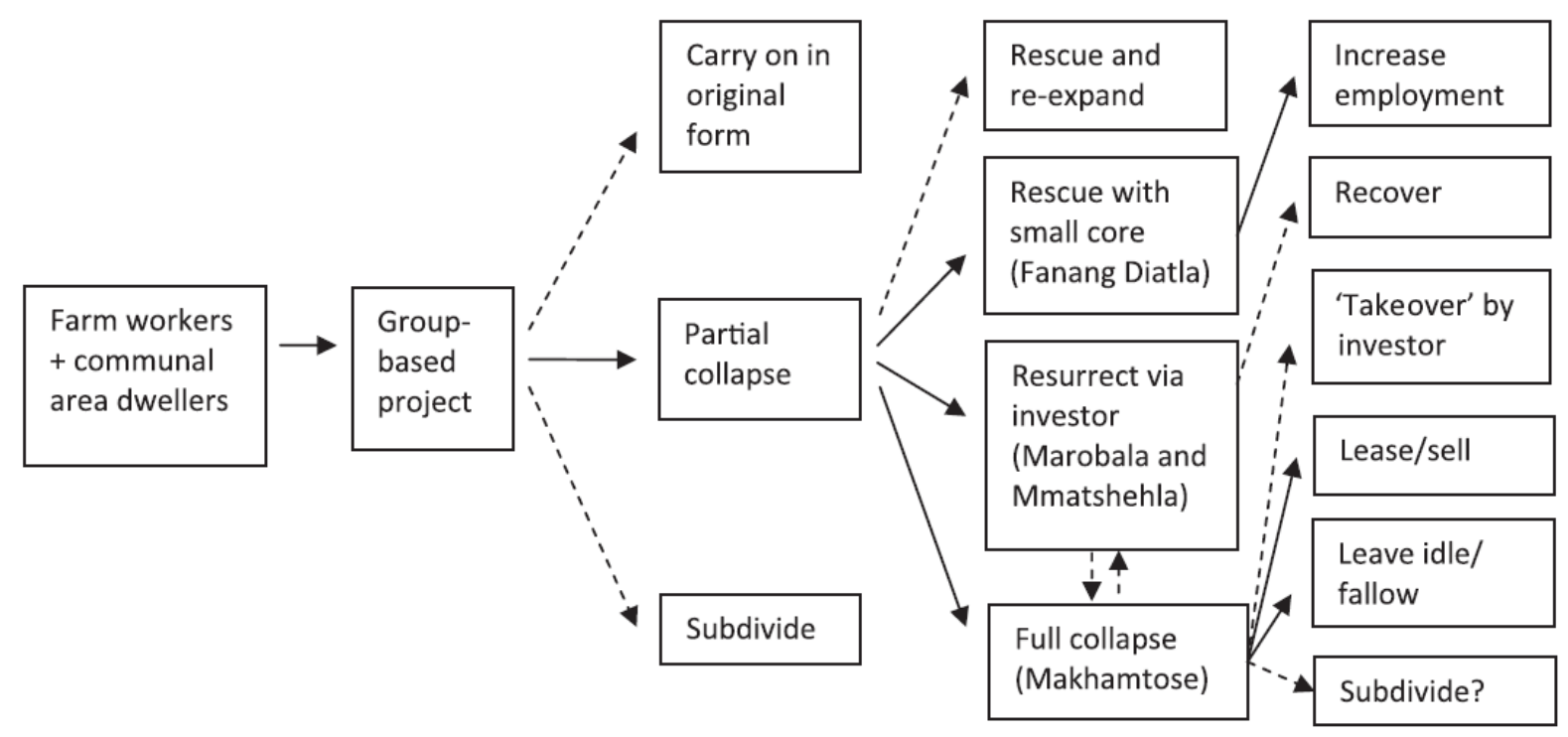

This was the trajectory for Marobala Chicken and Mmatshehla, which were probably on track to collapse altogether, but were revived to some degree by the arrival of an external investor with some capital and entrepreneurial know-how. We cannot predict what might 
happen next; at Marobala Chicken there was some indication that the investor might have withdrawn, in which case complete collapse looked inevitable. Another logical possibility is that after some successful seasons, the investor could withdraw and the remaining beneficiaries would be able to continue in his absence. A third possibility is that the investor could end up taking over the project completely; at one stage, this was a fear expressed by remaining project members at Marobala Chicken, perhaps because the investor was employing as many people from his own village as them, the owners of the land.

(iii) Another distinct possibility is that the project goes from 'partial collapse' to 'full collapse', as with Makhamotse. However, it is not entirely clear how significant the distinction is between 'partial collapse' and 'full collapse'; certainly it is difficult empirically to draw a clear line between the two. We are aware of numerous SLAG projects outside of our case studies where land has ended up as completely idle or leased out to a non-project member; for example, a white farmer. We could also imagine, on the other hand, that remaining beneficiaries or someone else starts making use of the idle land, whether or not it is formally subdivided.

The distinction between leasing out and entering into a joint venture is somewhat ambiguous. From the perspective of the few remaining beneficiaries, the difference is real in that wages tend to be more significant than (a share of) the rather low rental income. However, in the case of Marobala Chicken, the 'joint venture' option exposed a hazard: the investor at one stage appeared poised to take over the project, seemingly with the consent and support of government officials. Of course, the same might occur in projects where land is leased out, but we have not observed any such cases.

Deference to the LSCF model is the main explanation for the design of SLAG-based redistribution projects predicated on preserving the previous owner's approach to production, and in particular the failure to subdivide properties when they are transferred or later. The consequence is unworkable 'projects' that either adapt or die. Different forms of adaptation are observed, the most auspicious of which is Fanang Diatla. One aspect of its adaptation was its dramatic shrinkage in active membership, from forty-nine to three beneficiaries. Another relates to the question of 'employment'. Characteristically, newly launched SLAG-based projects are designed so that project beneficiaries treat themselves as employees who earn a regular wage, rather than farmer-entrepreneurs who claim the residual after all other expenses have been paid. Following the near-collapse of Fanang Diatla, the remaining beneficiaries stopped behaving like beneficiary-employees and more like farmer-entrepreneurs. As their enterprise grew, they needed to hire additional workers, and for the most part were able to do so. But the rigours of farming made responsibility for paying regular wages difficult, and they required their employees to adopt some of the same flexibility and patience that they were forced to exercise themselves. In other words, they assimilated to a model of commercial farming more akin to that still prevalent in the former homelands than in the LSCF sector. 


\section{LRAD-Based Land Redistribution Projects, 2001-2009: Case study of Schaaphoek farm/Sadiki Cattle Enterprise.}

Schaaphoek was a white-owned cattle farm established in the 1920s, became an LRAD project (Sadiki Cattle Enterprise) in 2005, and was transferred to the Nthabalala community through the restitution programme in 2009. 3 We explore the story of Schaaphoek's redistribution through the experiences of three individuals:

Thomas M, who was a sometime farm worker there; Mr R, who leased part of the property for a few years; and Dr Sadiki, the LRAD beneficiary.

Thomas M was born in 1950 on Schaaphoek into a labour tenant family, and began working on the farm from the age of nine. At 17, he migrated to Johannesburg, where he worked in menial jobs for about 30 years. In his late forties, he decided to return to Limpopo, and moved from one farm job to another. In 2003, he ended up working on Schaaphoek again, but resided in a communal area village nearby. In 2005, Schaaphoek was bought by Dr Sadiki, a medical doctor based in Polokwane, the provincial capital, with the support of an LRAD grant. Dr Sadiki increased Thomas' wage relative to what he earned under the previous owner. Even so, when Thomas passed away in 2008, he died a poor farm worker, his circumstances not very different from those he experienced as a teenager.

Thomas' life history is probably typical of many farm workers turned migrants, whose life chances are not much improved by their stay in the urban economy. Some returned migrants, however, manage to accumulate some capital while working in the city and establish small businesses on their return to rural areas (see Neves and du Toit in this special issue). Mr R, for example, was also born on Schaaphoek, and at around the same time as Thomas, but managed to secure employment as a bus driver in Johannesburg for 20 years and received a modest severance package when his employment ended. Upon returning to Limpopo in 1991, he bought a truck and began hauling sand for building purposes, and then established a small butchery in Maila, the communal area village adjacent to Schaaphoek. He also purchased cattle, which he kept on the commons around the village. In around 1995, Mr R approached the Department of Land Affairs for assistance to acquire land, and believes he is 'on the list' to get such land. However, he has never heard back from Land Affairs, and has never pursued the matter further. The reality is that there is no such list, and it is unlikely that he will ever hear from government regarding his 'application'.

In the meantime, Dr Sadiki purchased the nearby Schaaphoek farm, and Mr R began leasing some of the farm's grazing land for his cattle. This suited Dr Sadiki, because the land leased to Mr R served as a buffer between Maila and the rest of Dr Sadiki's farm. Indeed, the white farmer who preceded Dr Sadiki at Schaaphoek had used precisely the same strategy to protect his grazing from villagers' livestock. Having such a buffer was all the more important to Dr Sadiki because of his heavy professional and business commitments in the provincial capital, which allowed him to visit his farm for only a few

\footnotetext{
3 Apparently, when the land was transferred to Dr Sadiki in 2005, the section of the Department of Land Affairs responsible for land redistribution was not aware of the fact that the farm was subject to a land claim.
} 
hours a week. He thus earned the epithet 'cellphone farmer', which was increasingly used after the rollout of the LRAD programme.

At some stage, government officials realised that Schaaphoek was subject to a land restitution claim by the Nthabalala Royal Council, which subsumes the neighbouring community of Maila. In 2009, the state acquired the farm from Dr Sadiki, who was paid out several times the value of his total investment in Schaaphoek. The consequence for $\mathrm{Mr}$ $\mathrm{R}$ was ironic: as a member of the claimant community, he was now a part owner of Schaaphoek but no longer had exclusive access to a section of the farm, and was unsure whether it was still worth his while to maintain the watering point and other infrastructure that he had used as a tenant of Dr Sadiki.

Mr R's story shows that, in contrast to Thomas, the capital he accumulated while a migrant worker meant that he had various options on his return to Limpopo, albeit that, in contrast to Dr Sadiki, he did not have sufficient resources to enable him to acquire his own land.

Figure 2 LRAD project trajectories

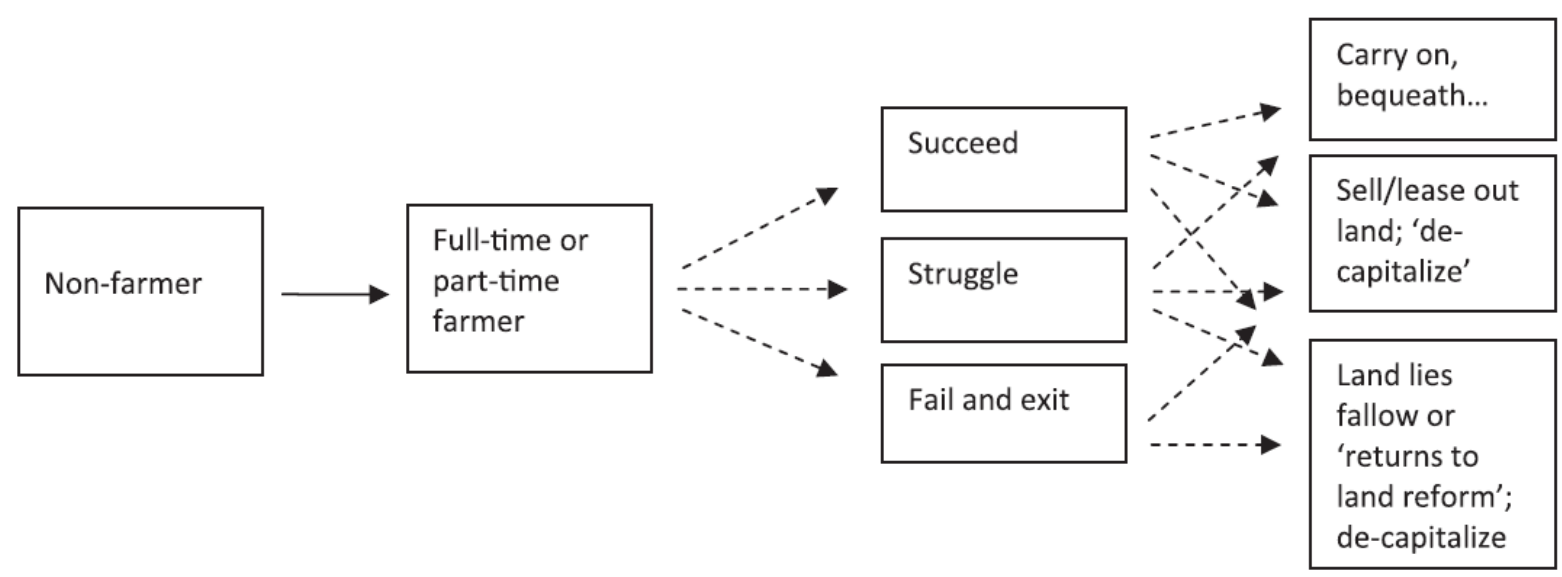

As a restitution beneficiary, $\mathrm{Mr} \mathrm{R}$ was uncertain whether his cattle farming would be constrained by the fact that the effective claimant group was large relative to the grazing capacity of Schaaphoek farm. 4 Also of interest is that Thomas' relationship to the new farm owner was little different to that which had obtained in the past. The maintenance of Schaaphoek as a large-scale commercial farm meant that the authoritative character of the owner-worker relationship was preserved, even though Dr Sadiki may have been a slightly more generous employer than his predecessor, possibly because he had access to sources of income other than farming.

\footnotetext{
${ }^{4}$ The claim lodged by the Nthabalala Royal Council included only about fifty households, Chief Nthabalala acknowledged that at the time of compiling the list, many community members did not see the purpose of including their names, or were living elsewhere and could not be contacted. Chief Nthabalala's expectation was that once the land was restored, more households belonging to the community would be interested. Indeed, as of late 2011, more than forty households had settled on the part of Schaaphoek near the main road. Otherwise, the land is used for communal grazing. It is not clear whether competition for grazing has increased.
} 


\section{Trajectories of LRAD-based projects.}

The four LRAD project case studies have trajectories that are simple and similar to one another (Figure 2). The main difference among them is that in two of these projects (Springkaan and Goedgedacht Estate) the main beneficiary became a full-time farmer, while in the other two (Sadiki Cattle Enterprise and Karishume) he became a part-time farmer. While each of these farms is managed by one individual, typically the 'official beneficiaries' include both this individual and a handful of close relatives; in one instance (Goedgedacht Estate), the individual managing the farm is not an official beneficiary at all; rather, he runs the farm on behalf of his uncle and cousins. One implication is that the official statistics regarding LRAD beneficiaries are highly misleading, albeit not to the same extent as with SLAG.

To date, there is little discernible variation in the paths of the LRAD projects, apart from the disruption caused to Sadiki Cattle Enterprise when its land was taken back for a restitution claim, and the expected disruption to Goedgedacht Estate for the same reason. The livelihood implications of the trajectory thus far appear to be modestly negative to modestly positive, mainly depending on the degree to which the new owner has succeeded in overcoming initial obstacles to establishing him- or herself as a farmer. Thus Springkaan appeared to be losing money, but with the promise of becoming profitable in the near future; Dr Sadiki was on the threshold of breaking even before he had to surrender his farm. Goedgedacht Estate and Karishume were doing modestly and very well, respectively, due to different levels of technical competence, marketing acumen and initial resources available.

One interesting feature of the Karishume and Springkaan cases is diversified and intensified production subsequent to redistribution. For Springkaan, this involved expanding the beef cattle enterprise and adding irrigated vegetables. This was not difficult because the cattle production system at the time of land acquisition was not very intensive. Karishume started with broiler production and then, within the very small amount of land available to it, both expanded the broiler operation and diversified into vegetable production.

The possible future trajectories indicated by the first set of dashed lines merely suggest different 'points' along a continuum of success/failure with different logical outcomes, namely that land remains in use by the individual or family, that it is sold in the market or leased out (in which case it is more than likely to return to white ownership and/or use) or that it is returned to land reform, which is especially likely if it is repossessed due to an unserviced Land Bank loan. 'De-capitalization' refers to what has been observed on a large number of other failed land reform projects, where farm improvements are vandalized or fall into disrepair.

Are there other possible trajectories? It was clear from the project census that among projects where nothing was happening at the time of the interviews, a fair number were LRAD projects. The apparent robustness of our case studies should not be taken to imply that LRAD projects are inevitably successful: the more common trajectory is one of extinction. 
Is diversification a means of promoting survival? It is clear that diversification can promote a more sustained cash flow; thus the owner of Goedgedacht Estate, for example, whose main focus is on cattle production, relies on cash crops to generate enough income with which to pay his workers. Diversification has its own risks: investment in irrigation infrastructure by the owner of Springkaan may well prove a great benefit, but having lost his first cabbage crop to pests and his first tomato crop to frost, the outlay has placed him in a vulnerable situation in the short term.

The influence of the LSCF model is most obvious in the case of LRAD-based projects. LRAD projects are designed to approximate the LSCF model closely. To some extent, LRAD has been successful in terms of its own objectives but, interestingly, this is due not only to the ability to adopt the previous owners' farm plan, but to some beneficiaries' success in intensifying land use. It is clear that the farming systems put in place by LRAD beneficiaries do not depart radically from what the previous owners were doing, although, at Springkaan and Goedgedacht Estate, there is evidence that beneficiaries have exerted themselves to intensify land use and diversify enterprise mix compared with the previous owners.

\section{Restitution Projects: Case study of Vleifontein farm/Mavungeni.}

The history of the Mavungeni land claim to Vleifontein farm involves dispossession and the imposition of labour tenancy on those who lost their land, a common pattern in this part of Limpopo (Manenzhe and Lahiff 2007). After the initiation of the land restitution programme in 1994, two different groups lodged claims for Vleifontein farm; these claims were then consolidated through the encouragement of the Restitution Commission. The final, consolidated claim was finalized in 2002 on behalf of 200 claimant households; as with many restitution projects in Limpopo, the final tally of claimant households is an implausibly round figure.

The restored land comprises a 745 hectare portion of the farm Vleifontein, wedged between one of the few remaining white-owned commercial farms in the area and Vleifontein, a rural township of around 6,100 people. For the previous 30 years, the property had been state land; a 25 hectare fruit orchard had been leased to the white commercial farmer next door, a few hectares were used on an informal basis by township residents for dryland crop production, and the rest was more or less idle.

A CPA was formed and a CPA committee elected to represent its interests. However, the Mavungeni claim comprises a complex overlay of conflicts, both historical and current in nature. The core issue in relation to which the claimant group is overtly divided is settlement: where on the farm should settlement be allowed, and what kind of settlement? One view is that the settlement should be located as close to Vleifontein township as possible, to link up with the bulk service infrastructure that already exists in the township (water, sanitation, electricity and so on). In this vision - detailed in a plan developed by a consultant in 2005 - the Mavungeni settlement would be either an extension of the township or, alternatively, a new township adjacent to Vleifontein, with subsidized housing, business sites, a school and sites for two churches (Manenzhe and Lahiff 2007, 12). Another feature of this plan is that it provides for an expansion of commercial agriculture on the farm, building on an earlier business plan, commissioned 
by a different consultant, which stated that much of the land was suitable for crop farming and fruit orchards.

The opposing view is that of a group of 'invaders', who preferred not to wait for formal township development and wanted to establish their own homesteads on the land as soon as possible. By 2008, these 'invaders' had demarcated more than thirty plots, on which some had erected rudimentary shelters, and were engaged in small-scale farming of maize and other crops. These plots were not near to Vleifontein township, but were clustered along the northern boundary of the property, which happens to coincide with a tarred road, allowing easy access to nearby towns such as Elim. After 2008, however, the number of land users and residents seen as 'invaders' dwindled somewhat, apparently because they felt intimidated by threats of litigation by the other faction, or by the local municipality. In the words of the man widely regarded as the de facto leader of the invaders, James: 'Those who do not want us to be here are not hungry.'

By this, he meant that the invaders were there out of need, whereas those opposing them had the leisure of waiting for their formal plans to unfold. 'Invaders' also commonly accuse those opposing them of wishing to lease out the land to neighbouring commercial farmer; according to James, such people are '. . . traitors who are lazy and believe in the white man's magic of farming and think that a black person cannot farm'.

One of those most vehemently opposed to the 'invaders', Ezekiel, expressed his concerns thus: 'They want Mavungeni to become like Munzhedzi; they are invaders because they are violating the plan.' (Munzhedzi is the name of a restitution project on the other side of Vleifontein township, where almost 1,00o households have established homesteads; see below.) It is not clear that these two competing visions for the future at Mavungeni are incompatible. It is unlikely that commercial farming on a large scale will be initiated in the short to medium term, and proximity to the main road appears to be the crucial consideration for the location of plots established by the 'invaders'. In other words, there is little reason to expect that, left unchecked, spontaneous settlement at Mavungeni would extend significantly southwards on to land suitable for farming. $5^{5}$ Another concern expressed by Ezekiel is that the 'invaders' are not all bona fide claimants. Some acknowledge that they are not on the official claimant list, but assert that they are related to those who are, and that if the CPA committee would only agree to conduct a review of its membership, it would soon discover that their grandparents had links to the land and thus that they should be counted among the claimants.

James himself claims that he was born on Vleifontein farm in 1966, and his parents were also born there. James was 3 years old when the family was removed to Riverplaas, about 10 kilometres south-east, in what was then considered the Venda 'homeland'. After living

\footnotetext{
${ }^{5}$ The other instance of an alleged conflict of interest between the 'invaders' and the proponents of 'the plan' is that the settlement near the road is very close to a war memorial that forms part of the so-called 'Zoutpansberg skirmishes route'. This is a recent attempt supported by Soutpansberg Tourism and private tourism operators to create a tourist attraction from a collection of sites in northern Limpopo associated with episodes from the South African (AngloBoer) war. According to Ezekiel, the presence of the 'invaders' reduces the possibility that the Mavungeni community will find a way to capitalize on 'their' tourist stop: 'They have destroyed everything, they have stopped development, they are destroying the attraction there. 'The irony is rich: a black claimant community seeking to benefit conomically from a tourist site that marks the contest between two white powers for control over black people's land.
} 
and working in Johannesburg for some years, he returned with a wife and children to Limpopo at the age of 38 , and learned that the Mavungeni land claim had been successful. When the CPA committee rejected his request to use some of the land for farming, he decided to invade.

Shortly thereafter, he started crop farming, which he credits with saving his family from poverty. In a typical year, he produces more than enough maize to meet his household's needs, and he takes the surplus to his parents and other relatives who remain at Riverplaas.

A good example of someone who is 'not hungry' is Jonas M, a retired school principal who now serves as Deputy Secretary of the CPA committee. He was born on the farm Vleifontein farm in 1941, and grew up there with his parents. His father was a farm supervisor, and was on good terms with the farm manager at the time. This probably explains why Jonas' family was not removed from the farm at the same time as most of the others. Jonas' family was still present on the farm when Jonas attended a teacher training course and was then employed at a nearby school. Jonas had twenty-nine cattle on the farm, for which he was supposed to pay a grazing fee, but by 2009 the CPA had yet to decide on what these fees should be. Although Jonas is respected by other beneficiaries and is an influential member of the CPA committee, some feel that he capitalizes on divisions within the CPA membership to exploit project resources such as funds, access to grazing and the use of the project's tractor.

\section{Trajectories of restitution projects.}

Restitution projects in central-north Limpopo are highly diverse, partly because some are established on unutilized land (Munzhedzi), while others involve the restitution of subtropical fruit plantations (e.g. Levubu) or even nature reserves (Manavhela). Even so, many of them face similar challenges, such as complex internal group dynamics, opportunism by some claimants at the expense of others and contested decisions regarding land use (e.g. settlement versus production).

Abstracting from the complexities, we note six distinct observed trajectories, one possible (non-observed) trajectory and one noteworthy 'non-trajectory' (Figure 3). The trajectories include: spontaneous settlement (Munzhedzi, and to a limited degree Mavungeni); the use of land for communal grazing (Munzhedzi and Mavungeni, although these were not necessarily dominant land uses there); the use of the land for group-based production (Manavhela and, to a limited degree, Munzhedzi); the use of the land for individual production (Munzhedzi and Morebene); entering into a strategic partnership (the Levubu cluster and Manavhela); and leasing out (Manavhela, Morebene and Magkato).The nonobserved trajectory (dashed arrow) is 'planned settlement', as distinct from the unplanned settlement of Munzhedzi. The stalled township development at Mavungeni described above is a case in point. To reflect these frustrated processes, we refer to them as a 'non-trajectory' of 'waiting': the idea of things not happening whether because of lack of common will, expected resources or someone to take decisive action. 
Figure 3 Restitution project trajectories: (a) Munzhedzi and Mavungeni; (b) Munzhedzi and Mavungeni; (c) Mavungeni, Levubu and Manavhela; (d) Munzhedzi and Mavungeni; (e) Morebene, Manavhela and Levubu; (f) Mavungeni and Manavhela; (g) Mavungeni, Manavhela and Morebene

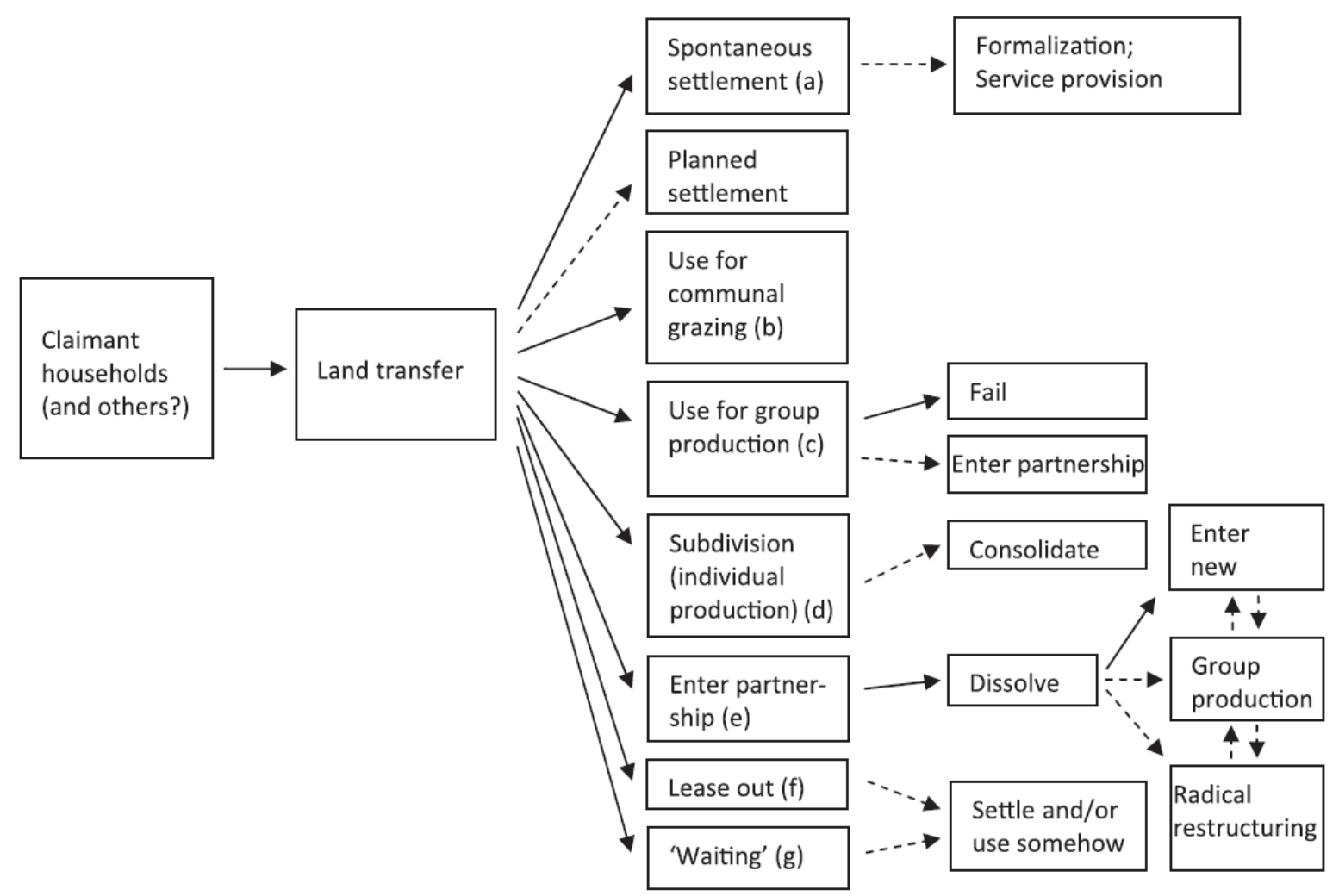

But 'waiting' is not only to do with stalled settlement. At Morebene, the majority of the restored farms have stood idle for several years. At Magkato, a vast restitution project west of Morebeng, the gerontocracy that is the project committee spoke wistfully of farming the land as in the old days, but acknowledged that their children and grandchildren had no interest; thus nothing happened.

What of the next phase/stage of these trajectories? From 'spontaneous settlement', a possible future course might be formalization and/or service provision by local government. At Munzhedzi, formalization has not happened, although some service provision (e.g. electricity) has begun, albeit slowly and imperfectly. 'Group production' is pursued in different ways in our sample, but mostly at a small scale. At Munzhedzi, there were a couple of small animal husbandry projects initiated with the support of a local NGO; the piggery closed down after 2 years, while the broiler project was still carrying on as of 2010, but with only a couple of individuals remaining active from the original dozen. While neither of these group enterprises was closely examined as part of this study, the impression is that they began struggling as soon as external support was withdrawn due to weak cash flow and poor management. Similarly, at Manavhela the group-based crop production enterprise collapsed within 2 years of being started, and the broiler enterprise a few years later, while the nature reserve has operated at a very low level (e.g. paying guests relative to capacity) since a year after transfer. For 'subdivision', the only example we have is Munzhedzi and the relatively small cluster of homesteads at Mavungeni. While, in principle, it is conceivable that consolidation could take place - even of the agricultural plots established apart from the area demarcated for settlement - it is difficult to imagine 
this happening, especially given that there are so many households and so little land seemingly available. From the 'enter partnership' scenario, it is possible that the partnership will carry on indefinitely, but at both Levubu and Manavhela these partnerships crumbled within 2-3 years. The Manavhela group sought a new partner in the hope that it would help stabilize the project in the face of chronic infighting; however, this arrangement itself lasted only a few months. Strategic partners tend to underestimate the complexity of working with 'communities', or find that government co-financing is tardy, or both. Radical restructuring, however, will always remain an option, if only in the background; for Levubu, this could, for example, involve subdividing the farms to create opportunities for small-scale orchard production.

The case that stood as out as benefitting large numbers of people was Munzhedzi, which did not proceed according to any plan, but was a restitution project 'gone wrong'. The land claimed was unused state land. After its transfer to the claimants' CPA, a selfappointed 'chief ' began demarcating plots and allocating them to anyone willing to pay a modest fee. The committee elected to manage the land on behalf of the claimants was unable to counteract the activities of the 'chief', one consequence of which was that as of 2009, there were 170 claimant households settled on the land plus around 800 nonclaimant households, many of which had relocated from nearby communal areas, but some also from 40 kilometres or further afield. ${ }^{6} 6$ The plots occupied by claimant and non-claimant households are intermingled and indistinguishable, and mainly consist of fenced plots measuring roughly 30 by 50 metres, containing self-built dwellings and gardens. About twenty to thirty of these residents - including both claimants and nonclaimants - also farm somewhat larger plots situated on the sloping terrain south of the settled part of Munzhedzi, and there is space for more such plots. Two dominant themes emerge from interviews at Munzhedzi: people appreciate the better agricultural conditions there, and its convenient location, close to a reasonably busy transport route from which they can get to local economic centres. As expressed by one woman who had settled at Munzhedzi, 'We are next to the road and the land is beautiful.' It would appear that Munzhedzi addressed a kind of land need not catered for in land reform policy.

The LSCF model is evident in restitution first and foremost in the effort to maintain the production systems of the former commercial farms that occupied the land. In some instances, this led to outcomes similar to SLAG-based projects, though arguably worse because of even greater numbers of beneficiaries; in others, the Restitution Commission deliberately sought to prevent problems associated with large group claims by bringing in a strategic partner. The case of Munzhedzi stands out in that it had no 'current use' to maintain, which together with other specific features, allowed a land-use pattern to emerge based on informal subdivision, with little resemblance to the other restitution projects examined, never mind the LSCF model. Mavungeni in a sense is torn between

\footnotetext{
${ }^{6}$ According to the chairperson of the CPA committee, 'If it was only claimants on this land, this settlement would have looked different; if it was the CPA committee allocating - it would look different, for example the streets are not planned, we would have made the houses a bit far apart ...' However, he indicated that claimants resigned themselves to sharing the property with non-claimants, and separate focus group discussions held with claimant and non-claimant households also indicated a high level of acceptance and lack of hostility. One reason may be that many non-claimant residents are related to claimants. Interviews suggest that that many claimant households did not move back to Munzhedzi as they did not any advantage in doing so. Non-relocation to restored land is common in land restitution (see, e.g., Walker 2008).
} 
competing visions of agriculture, with some preferring Munzhedzi-style homesteads that allow for small-scale agriculture, and others holding out for the commercial farm development promised in the consultant's plan.

\section{Contested farm models, social differentiation and livelihoods}

The study confirms the wide-scale failure and collapse of land reform projects in centralnorth Limpopo, but also: (1) highlights that even where projects have not failed, the benefits can be quite limited; and (2) identifies specific circumstances in which land reform has provided access to land that has enhanced the livelihoods of poor people.

We argue that the diverse outcomes are best understood in relation to the different ways in which application of the LSCF model has interacted with or informed the three main types of redistributive land reform projects. In short, the LSCF model conditions how agriculture is organized in land reform projects, who is involved in land reform and how different types ofpeople relate to one another on transferred land.

Farm dwellers and migrant workers are found in all three project types, but are employees (rather than land owners) in LRAD projects. Communal area dwellers and communal area farmers are almost systematically neglected by land redistribution: to the extent that either group featured in our case studies, it was generally as recruits to help populate SLAG applications that neglected their circumstances and interests, while for LRAD projects, communal area dwellers and farmers faced hurdles similar to those of farm workers and farm dwellers. Communal area dwellers tend to be beneficiaries in restitution rather than redistribution projects. Communal area farmers, however, are found in very few projects, with the important implication that their farming skills are not transferred to redistributed land. Middleclass beneficiaries such as teachers, civil servants and successful businessmen tend to be managers or investors in (resurrected) SLAG projects or in LRAD projects, and are also found in some restitution projects.

For SLAG-based redistribution projects, it is deference to the LSCF model that accounted for the generally unworkable project design, whereby a large beneficiary group attempted to maintain the production system of the previous commercial farmer. Because commercial farms in Limpopo and elsewhere had generally been designed over the years to rely as little as possible on labour, this meant that most beneficiaries were redundant from the outset. Rather than seeking to replicate or build on the labour-intensive, individualized production systems of the 'communal areas', group-based agriculture was encouraged or imposed within the commercial LSCF context, in the absence of robust farm management and despite some group members having contrary preferences. The result was collapsed projects; and on those that did not collapse, a dramatic attrition of beneficiaries. Curiously, subdivision was generally not effected as a means of rendering conditions more tenable, suggesting the tenacious grip of the LSCF model despite the possibility that some beneficiaries recruited from the communal areas might have preferred to subdivide. Perhaps the LSCF model has generally won out because SLAG projects have tended to be established around a core of former farm workers, to whom the LSCF model was familiar and attractive, as illustrated by the case of Makhamotse. 
The end result was that for those SLAG projects that adjusted and survived, a few former farm workers did benefit, and might in future develop and benefit further. However, the dominant pattern is the loss of farm-worker jobs, and virtually no new livelihood opportunities for residents of communal areas.

The influence of the LSCF model is most obvious in the case of LRAD-based redistribution projects, where a conscious attempt was made to ensure continuity with the farming practices of the previous owner, inevitably a large-scale commercial farmer. Indeed, the LRAD policy was designed with the idea of promoting continuity in recognition that SLAG-based projects did not work, and adherence to this principle at project level is due to the shared view of government planners and applicants.

Although the project census revealed that LRAD projects were as likely to collapse as SLAG-based redistribution projects and restitution projects, those that did not collapse tended to fare reasonably well, and without major adjustments. From a livelihoods perspective, however, LRAD projects contributed little to poverty reduction because they were elite-oriented, which the very modest labour intensification observed on some projects did little to compensate. LRAD conspicuously failed to incorporate the poor and vulnerable as its main beneficiaries, precisely because it succeeded in replacing sellerdriven land reform in the form of SLAG with applicant/beneficiary-driven land reform, which meant that it was the better-off, better educated and well-connected who sought and got assistance. For South Africa as a whole, between 2001-2 and 2005-6, only about 3,900 households benefitted from LRAD per year, while between 2006-7 and 2008-9 there were fewer than 2,000 households, despite annual expenditure in excess of R1 billion (Aliber et al. (forthcoming)).

This merely echoes what was observed above about the relative (and increasing) marginality of central-north Limpopo's commercial agriculture sector from a livelihoods perspective. Moreover, to the extent that LRAD succeeded in allowing the continuity of large-scale commercial farming, it also perpetuated unequal social relations between owners and workers. In other words, LRAD projects tend to maintain a strict class-based, farm management hierarchy that is absent in SLAG-based projects and perhaps helps to explain why they fail as commercial farms. In other words, where the LSCF model is applied to land reform, it imposes an invidious choice between non-functional equity (SLAG) or functional inequity (LRAD). In a sense, restitution projects tend to be extreme versions of SLAG-based projects, characterized by continuity with previous land use, but with beneficiary numbers that are large even by the standards of SLAG. Another typical feature of restitution projects in central-north Limpopo is that they have taken on 'strategic partners' as a means of ensuring good management, in the absence of which large group size would be especially destabilizing, But this again is predicated on maintaining the LSCF model in place, rather than seeking ways of altering land use to suit the needs and capabilities of beneficiaries. The exception noted above, of Munzhedzi, can perhaps be partially explained by the fact there was no prior commercial farming enterprise to maintain - the land had been effectively idle. Moreover, the lack of effective control by the CPA committee allowed a more spontaneous expression of need, namely land for homesteads with productive conditions for gardening and some smallholder 
production. The 'invaders' at Mavungeni also demonstrate alternatives to the 'white man's magic of farming': small-scale farming for home consumption and sale.

Taking SLAG, LRAD and restitution together, it is apparent that poverty reduction benefits are mainly available to those who fall outside the intended project plans. And, strangely enough, these opportunities appear to be concentrated in restitution, where the main design parameters of 'which land for whom' are beyond the reach of policy-makers and implementers. The reason is perhaps that restitution is even more apt to lead to dramatic levels of conflict. It seeks to impose a socio-political unity, for example, by reaffirming the cadastral property boundaries bequeathed from the colonial era, on the assumption that this is an adequate depiction of claimants' lost 'property'; by consolidating the claims of distinct groups for the convenience of post-1994 government administration; by finalizing claimant lists for the same purpose; and by requiring claimant groups to form CPAs and elect officers. However, attempting to match a finite, formally represented group to a well-defined unit of land suggests a socio-political unity that often does not exist in practice. The conflict that tends to follow opens up space for the sort of invasions that have occurred at Munzhedzi and Mavungeni.

Two types of beneficiaries have been systematically neglected by land reform in Limpopo. Although government appears to have always regarded farm workers and farm dwellers as a key target group, SLAG and LRAD have done little to benefit farm workers in practice. For LRAD, the applicant-led nature of the application process has meant that farm workers are relatively unlikely to apply; there is a clear bias in favour of those who possess better-than-average resources, education and social networks, which farm workers and dwellers by and large lack. By contrast, SLAG, because it has lent itself to seller-driven projects, has gravitated almost unerringly towards farm workers but, as argued above, often in a manner that marginalizes them even further rather than providing real benefits. Communal area dwellers and farmers have also been neglected by land redistribution.To the extent that either category has benefited, it has generally been as recruits to help populate SLAG applications with little relevance to their situation or their interests. For LRAD projects, communal area dwellers and farmers have faced hurdles similar to those of farm workers and farm dwellers. Because of this, the large proportion of black farmers who are women have derived little benefit from land redistribution. Significantly, the one case study project that did accommodate communal area dwellers and farmers - Munzhedzi - was the one that was least planned.

\section{Livelihoods after land reform in Namibia and Zimbabwe}

The problematic application of the LSCF model to land reform in central-north Limpopo is explained above in terms of the particularities of South Africa's land reform programme. However, even in land reform policy contexts that are quite different, the LSCF model is found wanting. This section summarizes findings from the Namibian and Zimbabwean components of the LaLR study, focusing on the constraints experienced in applying the LSCF model or, alternatively, the advantages of not applying it.

\section{Namibia}

Namibia is a largely arid and semi-arid country, in which most agricultural production is extensive livestock ranching. Only 8 per cent of the country receives an average annual 
rainfall of more than 500 millimetres (Werner and Odendaal 2010, 18). The government's land redistribution programme involves purchasing large-scale commercial farms from 'willing sellers', subdividing them and allocating the new units to 'small-scale commercial farmers'. The main resettlement model is the Farm Unit Resettlement Scheme (FURS), in which individual beneficiaries are allocated a 'small farm' (i.e. small relative to local norms), specified as a minimum of 1,00o hectares in the wetter areas of the north of the country, and 3,000 hectares in the drier south. They then enter into a long-term lease agreement with the government (Werner and Kruger 2007, 13).An Affirmative Action Loan Scheme (AALS) provides funds for purchase of commercial farms by black Namibians, with the objective of encouraging large herd owners from communal areas to 'become fully-fledged commercial farmers' (ibid., 14). A minimum of 150 Large Stock Units (LSU) must be owned by applicants for AALS loans, which are subsidized for the first 10 years. By 2005, a total of 625 farms across the country had been acquired through AALS, compared to 163 farms under FURS (ibid., 17).

The LaLR project in Namibia examined the livelihood impacts of land redistribution in two regions, Hardap and Omaheke. The study involved the collection of both quantitative and qualitative data on a small sample: nineteen FURS beneficiaries in Hardap and twenty in Omaheke, together with ten AALS farmers in Hardap and five in Omaheke. Typologies of different livelihood trajectories were developed for all three models, based on the diverse livelihood strategies pursued by beneficiaries.

Werner and Odendaal argue that for the objective of establishing self-supporting smallscale commercial farming, the current FURS model 'does not appear to be commercially viable or financially sustainable' $(2010,166)$. Minimum farm sizes of 1,000 hectares in the north and 3,000 hectares in the south have the potential, when climatic conditions are optimal, to generate gross margins of $\mathrm{N} \$ 37,500$ and $\mathrm{N} \$ 60,480$ per annum respectively, insufficient for capital investments for maintenance and replacement of fencing and boreholes. At recommended stocking rates, it would be impossible for a FURS farmer to ever attain the minimum herd size (of 150 LSU) required to qualify for an AALS loan, and thus 'graduate' to large-scale commercial farming (ibid., 166-7, 170). In Omaheke, the FURS model does not cater for farmers with herds more than 70 LSU (the maximum on 1,000 hectares, at recommended stocking rates) but less than 150 LSU (ibid., 121). But in most cases, actual farm sizes are much smaller than these 'minimums'.

The study concludes that the prevailing models for resettlement are limited and restrictive', 'too narrow' and 'not well matched with the needs, aspirations and expectations of many beneficiaries, particularly those who have few assets. Current land reform thinking assumes that every beneficiary intends to become a small-scale or largescale farmer', but beneficiaries are more differentiated than is commonly recognized (ibid., 168). Other policy options, such as small-scale irrigation schemes for urban markets, enlargement of communal areas, co-operative ranching or joint ventures, have not been explored to date. One key issue is farm size, which is a key constraint on beneficiaries who try to expand their herd sizes and aspire to acquire a larger farm through an AALS loan. The 'rigidity' of the FURS model constrains accumulation (ibid., 121).Werner and Odendaal recommend a review of resettlement models, farm sizes and beneficiary selection criteria, as well as clarification of the leasehold land rights of 
beneficiaries, more effective post-settlement support, investment in infrastructure and coordinated planning (ibid., 172-6).

\section{Zimbabwe}

The Zimbabwe study has been reported in a book and two journal papers (Scoones et al. 2010, 2011, 2012) and its findings widely debated. Research was undertaken on land formerly held as large-scale commercial farms, subject to farm occupations after 2000, and transferred under the Fast Track Resettlement Programme (FTLRP). Field work was undertaken at sixteen sites and four research clusters across Masvingo province, much of which is dry, averaging less than 500 millimetres of rain per annum. (Scoones et al. 2010, 38-41). Former land uses included extensive livestock ranching on most farms, and irrigation farming (including sugar cane) at a few sites. On the basis of the study's findings, the authors argue that five widely held 'myths' about land reform in Zimbabwe have little empirical basis in Masvingo province: that agricultural production has collapsed following the FTLRP, food insecurity is widespread, the rural economy is in rapid decline, little new investment in land has occurred and the beneficiaries of land reform have been political 'cronies' of the ruling party (ibid., 8). The study's findings contradict these stereotypes, and show that while the effects of post-200o land reform in Zimbabwe are complex, differentiated and dynamic, secondary data suggest that the situation in Masvingo is not unique. The findings also reveal sharp differences with South Africa and Namibia, as well as some similarities.

One key difference with South Africa and Namibia is that land redistribution has radically reconfigured Zimbabwe's agrarian structure. By 2008-9, over 4,500 large-scale commercial farms, comprising 7.6 million hectares in total, had been redistributed to over 145, ooo households in the smallholder-oriented A1 resettlement schemes, with around 16,500 beneficiaries occupying medium-scale, commercial farms, the A2 model. There are also many 'informal' resettlement sites not yet recognized by the government. Some larger A2 farms, akin to the large-scale commercial farms of the past, have been allocated more recently, and Moyo $(2011,497)$ suggests that total land allocations under FTLRP now amount to 9 million hectares. In 2011, around 3.4 million hectares were still under largescale farms, some in very large holdings, with about 200 white farmers occupying 117,000 hectares, and black Zimbabweans owning around 950 large farms (ibid., 514). Including communal areas and 'old' (pre-200o) resettlement schemes, 98 per cent of all farms in Zimbabwe are now smallholdings (Scoones et al. 2010, 6; Moyo 2011, 942).

The FTLRP instituted radical shifts in agrarian structure in Masvingo province, too. About 28 per cent of the total land area, or 1.2 million hectares, was transferred to 32,500 households on A1 sites, and to 1,200 households on A2 farms, with 8,500 households in informal sites (Scoones et al. 2010, 33-4). The average size of the A1 farms in the study was 37 hectares, including cropping and grazing land, compared to a mean of 318 hectares for A2 farms - but in practice there are many similarities between smaller A2 farms and a variant of the A1 model, the 'self-contained A1 schemes', which include individual grazing land, in contrast to the communal grazing of the A1 'villagized' model (ibid., 95). 
The study found that trends in the levels of production and sales of surplus were highly differentiated by climatic zone, type of resettlement model and 'success group' within each site.7 Maize production data between 2003 and 2009 shows gradual increases in total output at each site over this period, but with declines in severe drought years (ibid., 108). An increasing proportion of farmers at each site and resettlement model have been able to produce over a tonne of maize (the amount required for food self-sufficiency for a family of six), but mainly through expanding the area under maize rather than through yield increases (ibid., 111).

Production and sales vary considerably between success groups (SGs) 1 to 3 ; for example, in the A1 self-contained sites, some 65 per cent of SG1 sold twenty-one or more bags of maize in 2008-9, compared to 26 per cent of SG2 and 17 per cent of SG3 (ibid., 110-11). Similar patterns of differentiation are evident in relation to cotton production and livestock ownership. In contrast to A1 schemes, many A2 farmers 'are overwhelmed by the scale of their farming operations' and have struggled to become productive, in many cases constrained by lack of access to capital to invest in their farms (ibid., 123). A2 farmers in the sugar-cane sector have been constrained by inadequate access to inputs and by strained relationships with corporate owned large sugar estates (ibid., 115).

Technocratic approaches to rural planning have a long history in Zimbabwe and remain influential. Soon after farm occupations began, government officials were sent out to peg plots, hand out 'offer letters' and allocate farm units of a 'viable' size (ibid., 193). But formal planning soon ran up against informal planning by the leaders of farm occupations, which emphasized inclusion of beneficiaries rather than 'viability'. The outcomes of land redistribution were the result of 'a complex trade-off between local conditions, particular histories and contingent circumstances and the structuring forces of nationalist politics, technocratic planning models and local institutional arrangements, mediated by diverse forms of "traditional" and "modern" political authority, gender dynamics and social relations'. Land reform was not therefore, in this case, a top-down technocratic intervention (ibid., 237).

In conclusion, Scoones and his co-authors argue that a decade of large-scale land redistribution has unleashed a process of radical agrarian change, with many enjoying enhanced land-based livelihoods, and novel commodity chains and market linkages of much potential beginning to emerge. Problems and challenges abound, however, in relation to insecure land tenure, unaccountable systems of land administration, and absent or weak support services for supplying inputs, credit, infrastructure and extension. The potential of the new agrarian structure to put accumulation from below on a firm foundation, and deliver improved livelihoods on a sustained basis, will thus require appropriate state polices and investments if it is be realized (ibid., 241).

\footnotetext{
7 Data on success groups were collected using indicators and rankings devised by local respondents in each site. Rankings (i.e. categorization as Success Group 1, 2 or 3) correlated with a range of quantitative indicators of success,
} 
Comparing key findings from the three country studies, both similarities and differences can be identified (see Table 3). Land reform models have varied between countries, but in each case project planning has been premised on the need for 'viability', its criteria drawn, explicitly or implicitly, from a hegemonic LSCF model. The inappropriate business plans imposed on beneficiaries in South Africa, the highly constrained nature of the 'small-scale commercial farms' established in Namibia and the lack of capital available to A2 beneficiaries in Zimbabwe have all hamstrung land reform. In Zimbabwe, however, A1 schemes for small-scale producers have been much less subject to the LSCF model, in part because of greater acknowledgement by government of the productive potential of smallholders, and in part because official planning was generally overtaken by local processes that enabled beneficiaries to make their own key decisions. The disabling apparatus of planning informed by the LSCF model has had less purchase, and there has been greater scope for beneficiary households to establish their own farming systems, often supported by non-farm income of various kinds. Furthermore, across all three countries, post-settlement support for land beneficiaries (inputs supply, extension, training, credit, infrastructure development, marketing etc.) has been weak and ineffective.

As a result of inappropriate planning, a significant proportion of land reform projects or schemes in the research sites have 'failed' on the criteria of land underutilization, low levels of productivity and the exit of beneficiaries. The striking exception, again, is A1 resettlement schemes (both 'villagized' and 'self-contained' versions) in Zimbabwe, where small-scale, household-based forms of agriculture predominate. In South Africa, the Munzhedzi case, where a restitution claim had 'gone wrong' and hundreds of nonclaimants were allocated plots, suggests the need to consider a land redistribution process based on the subdivision of large farms and support for small-scale, part-time farming as one of many livelihood sources.

Overall, the impacts of land redistribution on the livelihoods of beneficiaries and others have been mixed in all three countries. 'Failure' and exit are evident to a degree, but so are modest to substantial improvements. The Zimbabwe study shows that many smallholders located on A1 schemes in Masvingo province benefited from access to an expanded land base and, despite recurrent drought and problems in accessing crop inputs, some are beginning to engage in a process of 'accumulation from below'. Social differentiation before and after land reform means that across all three countries, some benefit from land transfers more than others; even in Zimbabwe's A1 schemes, a significant proportion of beneficiaries are managing only to 'hang in', while others 'drop out'. Land and agrarian reform by itself is clearly not the sole solution to rural poverty; complementary measures aimed at creating jobs and other kinds of livelihood options are needed as well. 


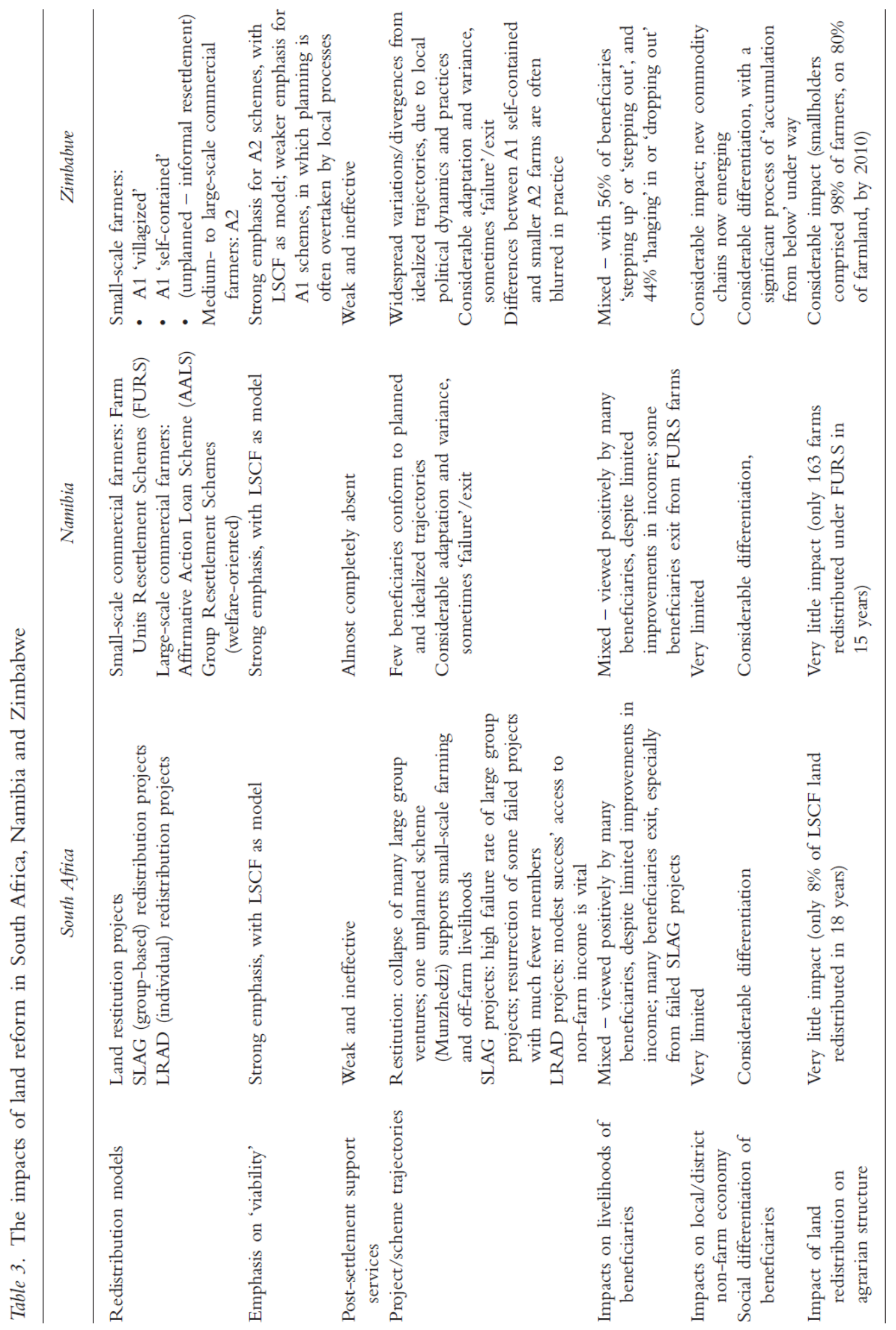


The most telling contrast between the three countries in the LaLR study is in relation to agrarian structure: only in Zimbabwe, where the scale of land redistribution has been much larger than in South Africa and Namibia, has the 'dualistic' structure inherited from the past been radically transformed, at least at Masvingo. This case suggests that smallholder farming on subdivided commercial farms has the potential to support large numbers of rural producers, and that small-scale agriculture combined with other livelihood sources can benefit many of the rural poor. Policies premised on the assumption that only LSCF is 'real agriculture', and that land reform projects must be based on some version of this model to be 'viable', are part of the problem, and often contribute directly to project failure. New thinking is required to inform policy and planning if land reform in South Africa and Namibia is to make more than a marginal contribution to poverty reduction. 


\section{References}

Aliber, M. and R. Hall, 2010. 'Development of Evidence-Based Policy around Small-Scale Farming'. Report commissioned by the Programme to Support Pro-Poor Policy Development, on behalf of the Presidency.

Aliber, M. and R. Mokoena, 2003. 'The Land Question in Contemporary South Africa'. In State of the Nation, eds J. Daniel, A. Habib and R. Southall, 330-45. Cape Town: HSRC Press.

Aliber, M., T. Maluleke, T. Manenzhe, G. Paradza and B. Cousins, forthcoming. Land Reform and Livelihoods:Trajectories of Change in Northern Limpopo Province, South Africa. Cape Town: HSRC Press.

Aliber, M., M. Baiphethi, R. de Satge, J. Denison, T. Hart, P. Jacobs and W. van Averbeke, 2009. Strategies to Support South African Smallholders as a Contribution to Government's Second Economy Strategy - Volume 1: Situation Analysis, Fieldwork Findings and Main Conclusions, Institute for Poverty, Land and Agrarian Studies Research Report No. 41, University of the Western Cape.

ANC (African National Congress), 1994. The Reconstruction and Development Programme: A Policy Framework. Johannesburg: Umanyano Press.

Bureau of Census and Statistics, 1953. Report on Agricultural and Pastoral Production, Sugar Cane Plantations and Timber and Wattle Plantations 1950-51: Agricultural Census Number 25. Pretoria: Bureau of Census and Statistics.

Cousins, B. and I. Scoones, 2010. 'Contested Paradigms of "Viability" in Redistributive Land Reform: Perspectives from Southern Africa'. Journal of Peasant Studies, 37 (1): 31-66.

CRLR (Commission on Restitution of Land Rights), 2004. Annual Report 2003-04. Pretoria: Government Printers.

Department of Agriculture, 1995. White Paper on Agriculture. Pretoria: Department of Agriculture, http://www.gautengleg.gov.za (accessed 4 June 2010).

Derman, B., E. Lahiff and E. Sjaastad, 2010. 'Strategic Questions about Strategic Partners: Challenges and Pitfalls in South Africa's New Model of Land Restitution'. In Land, Memory, Reconstruction, and Justice: Perspectives on Land Claims in South Africa, eds C. Walker, A. Bohlin, R. Hall and T. Kepe, 306-23. Athens, OH: Ohio University Press.

DLA (Department of Land Affairs), 1997. White Paper on South African Land Policy. Pretoria: Department of Land Affairs.

DWAF (Department of Water Affairs and Forestry), 2004. 'Luvuvhu/Letaba WMA: Internal Strategic Perspective'. Report No. P WMA 02/00o/00/0304. Pretoria: DWAF.

Fraser, A., 2007. 'Hybridity Emergent: Geo-history, Learning, and Land Restitution in South Africa'. Geoforum, 38: 299-311.

Hall, R., 2011. 'The Politics of Land Reform in Post-Apartheid South Africa, 1990 to 2004: A Shifting Terrain of Power, Actors and Discourses'. Unpublished PhD thesis, St Antony's College, University of Oxford.

Hebinck, P., D. Fay and K. Kondlo, 2011. 'Land and Agrarian Reform in South Africa's Eastern Cape Province: Caught by Continuities'. Journal of Agrarian Change, 11 (2): 220-40. 
Jacobs, P., E. Lahiff and R. Hall, 2003. Land Redistribution. Evaluating Land and Agrarian Reform in South Africa Series, No 1. Programme for Land and Agrarian Studies, University of the Western Cape.

Lahiff, E., 2007.“ "Willing Buyer,Willing Seller": South Africa's Failed Experiment in Market-Led Agrarian Reform'. ThirdWorld Quarterly, 28 (8): 1577-97.

Lahiff, E., 2010. 'Land Reform and Poverty Reduction in South Africa'. In Reforming Land and Resource Use in South Africa: Impact on Livelihoods, eds P. Hebinck and C. Shackleton, 58-85. London: Routledge.

Lahiff, E.,N. Davis and T. Manenzhe, 2012. JointVentures in Agriculture: Lessons from Land Reform Projects in South Africa. London: IIED/Rome: IFAD and FAO/Cape Town: PLAAS.

MALA (Ministry for Agriculture and Land Affairs), 2001. Land Redistribution for Agricultural Development: A Sub-Programme of the Land Redistribution Programme. Pretoria: MALA.

Manenzhe, T., 2007. Post Settlement Challenges for Land Reform Beneficiaries:A Case Study of Munzhedzi, Mavungeni and Shimange Communal Property Associations. Unpublished MPhil thesis, Programme for Land and Agrarian Studies, University of the Western Cape.

Manenzhe, T. and E. Lahiff, 2007. 'Restitution and Post-Settlement Support: Three Case Studies from Limpopo'. Research Report 30. Programme for Land and Agrarian Studies, University of the Western Cape.

Moyo, S., 2011. 'Three Decades of Agrarian Reform in Zimbabwe'. The Journal of Peasant Studies, 38 (3): 493-531.

Philip, K. and E.-K. Hassen, 2008. The Review of Second Economy Programmes:An Overview for the Presidency's Fifteen-Year Review. Second Economy Strategy Project.

Scoones, I., with N. Marongwe, B. Mavedzenge, J. Mahenehene, F. Murimbarimba and M. Sukume, 2010. Zimbabwe's Land Reform: Myths \& Realities. London: James Currey.

Scoones, I., with N. Marongwe, B. Mavedzenge, J. Mahenehene, F. Murimbarimba and M. Sukume, 2011.

'Zimbabwe's Land Reform: Challenging the Myths'. Journal of Peasant Studies, 38 (5): 967-94.

Scoones, I., with N. Marongwe, B. Mavedzenge, J. Mahenehene, F. Murimbarimba and M. Sukume, 2012. 'Livelihoods after Land Reform in Zimbabwe: Understanding Processes of Rural Differentiation'. Journal of Agrarian Change, 12 (4): 503-27.

Stats SA (Statistics South Africa), 2005. Census of Commercial Agriculture 2002: Financial and Production Statistics. Pretoria: Stats SA.

Stats SA (Statistics South Africa), 2007. Labour Force Survey March 2007. Stats SA data set on CD ROM.

Stats SA (Statistics South Africa), 2009. Census of Commercial Agriculture 2007. Pretoria: Stats SA.

Van den Brink, R., G. Thomas, H. Binswanger, J. Bruce and F. Byamugisha, 2006. Consensus, Confusion and Controversy: Selected Land Reform Issues in SubSaharan Africa.World BankWorking Paper No. 71.Washington, DC: The World Bank. 
Van Schalkwyk, H., J. Groenewald and A. Jooste, 2003. 'Agricultural Marketing in South Africa'. In The Challenge of Change: Agriculture, Land and the South African Economy, eds L. Nieuwoudt and J.A. Groenewald, 119-36. Pietermaritzburg: University of Natal Press.

Van Zyl, J., 1996. 'The Farm Size-Efficiency Relationship'. In Policies and Markets and Mechanisms for Agricultural Land Reform in South Africa, eds J. van Zyl, J. Kirsten and H. Binswanger, 259-309. CapeTown: Oxford University Press.

Vink,N. and J. van Rooyen, 2009. The Economic Performance of Agriculture in South Africa since 1994: Implications for Food Security. Development Planning Division Working Paper Series No. 17. Midrand: DBSA.

Walker, C., 2008. Landmarked: Land Restitution and Land Claims in South Africa. Auckland Park, SA: Jacana Media/Athens, OH: Ohio University Press.

Werner,W. and B. Kruger, 2007. Redistributive Land Reform and Poverty Reduction in Namibia. Paper for the 'Livelihoods after Land Reform' research project, http://www.lalr.org.za (accessed 4 July 2010).

Werner,W. and W. Odendaal, 2010. Livelihoods after Land Reform: Namibia Country Report.Windhoek: Legal Assistance Centre. 